\title{
EVALUASI MUTU BERAS DAN PENERAPAN GOOD HANDLING PRACTICE (GHP)) DAN GOOD MANUFACTURING PRACTICE (GMP) (STUDI KASUS PENGGILINGAN PADI DI KABUPATEN KARAWANG)
}

\section{EVALUATION OF RICE QUALITY AND APPLICATION OF GOOD HANDLING PRACTICE (GHP) AND GOOD MANUFACTURING PRACTICE (GMP) (CASE STUDY OF RICE MILLING IN KARAWANG REGENCY)}

\author{
Ekaterina Setyawati $^{1)}$, Sukardi ${ }^{2)}$, Yandra Arkeman ${ }^{2)}$ Muslich $^{2)}$ \\ ${ }^{1}$ Progam Studi Teknik Industri, Fakultas Teknik, Universitas Sahid Jakarta \\ J1. Prof. Dr. Supomo No 84 Tebet Jakarta \\ Email: eka3na.5@gmail.com \\ ${ }^{2)}$ Departemen Teknologi Industri Pertanian Institut Pertanian Bogor \\ Jalan Raya Darmaga, Kampus IPB Darmaga, Bogor 16680
}

Makalah: Diterima 12 Januari 2020; Diperbaiki 27 Maret 2020; Disetujui 5 April 2020

\begin{abstract}
Rice is still a strategic commodity in Indonesia, because it is still a staple food for most of Indonesia's population. Fulfillment of production must also be accompanied by aspects of quality fulfillment. This study aimed to evaluate the quality of rice and to evaluate the application of Good Handling Practice (GHP) and Good Manufacturing Practice (GMP) in small and medium rice miling in Karawang Regency. The performance of rice quality was evaluated based on the requirements for the rice quality class from the Minister of Agriculture Regulation Number: 31/Permentan/PP.130/8/2017 which includes water content, head rice, broken grains and whiteness degrees. Based on the results of quality of rice, it was found that the water contents in the medium and premium quality were $64 \%$ and $27 \%$, respectively. Based on the criteria for quality of head rice, it was obtained that all samples were not included premium quality and $22.2 \%$ in medium quality. For the criteria of broken grains, it was found $36 \%$ in medium quality and the other were below the quality standard. Meanwhile, based on the whiteness degree, most of the rice samples were included in the medium and premium rice qualities. The applications of GHP in rice milling were $42 \%$ for small rice milling and $50 \%$ for medium rice milling, whereas applications of GMP were 69\% for small rice milling and $92 \%$ for medium rice milling. Lack of socialisation regarding the importance of quality and implementations of GHP and GMP, and cost of risk that must be added by implementing GMP and GHP were factors caused the low quality of rice in Karawang Regency.
\end{abstract}

Keywords: rice quality in Karawang district, GHP, GMP

\section{ABSTRAK}

Beras hingga saat ini masih menjadi komoditas yang strategis di Indonesia, karena masih menjadi makanan pokok bagi sebagian besar penduduk Indonesia. Pemenuhan produksi harus pula dibarengi dengan aspek tepenuhinya mutu pasokan. Penelitian ini bertujuan untuk mengevaluasi mutu beras dan juga melihat penerapan Good Handling Practice (GHP) dan Good Manufacturing Practice (GMP) pada penggilingan padi kecil dan penggilingan padi sedang di Kabupaten Karawang. Kinerja mutu beras dievaluasi berdasarkan pada persyaratan kelas mutu beras dari Peraturan Menteri Pertanian Nomor: 31/Permentan/PP.130/8/2017 yang meliputi antara lain kadar air, beras kepala, butir patah dan derajat sosoh. Berdasarkan hasil analisis mutu beras di tingkat petani diperoleh bahwa kadar air beras bervariatif yaitu berkisar antara 7,1\% hingga 14,2\%, dan berdasarkan kelas mutu termasuk kedalam kelas mutu medium sebesar $64 \%$ dan kelas mutu premium sebesar $27 \%$. Sedangkan berdasarkan kriteria mutu beras kepala diperoleh bahwa seluruh sampel tidak termasuk dalam mutu medium ataupun premium. Kriteria mutu butir patah diperoleh angka kisaran 6,61\% hingga 33,8\%. Angka tersebut termasuk dalam persyaratan beras mutu medium sebesar $36 \%$ dan selebihnya masih dibawah standar mutu. Sedangkan berdasarkan derajat sosoh sebagian besar sampel beras termasuk kedalam persyaratan mutu beras medium dan premium. Dari hasil analisa dan wawancara, penerapan GHP di penggilingan padi masih sangat rendah yaitu sebesar $42 \%$ untuk penggilingan kecil dan 50\% untuk penggilingan sedang, sedangkan untuk penerapan GMP 69\% untuk penggilingan padi kecil dan $92 \%$ untuk penggilingan padi sedang. Kurangnya sosialisasi mengenai pentingnya mutu dan penerapan GHP dan GMP dipenggilingan beras, petani belum merasakan manfat dan nilai tambah dari penerapan GHP dan GMP, adanya resiko biaya yang harus ditambahkan dengan melakukan penerapan GMP dan GHP dengan baik, dan target pasar lokal yang dituju tidak membutuhkan persyaratan penerapan GHP dan GMP menjadi faktor penyebab rendahnya mutu beras di Kabupaten Karawang.

Kata kunci: mutu beras Kabupaten Karawang, GHP, GMP 


\section{PENDAHULUAN}

Beras merupakan komoditas pangan strategis dalam mewujudkan ketahanan pangan nasional. Dinamika yang terjadi pada sisi produksi dan sisi konsumen menyebabkan berbagai persoalan klasik muncul dalam agroindustri perberasan di Indonesia. Setiap periode sering terjadi kelebihan produksi sebagai akibat panen raya yang terjadi di sentra produksi sehingga menyebabkan petani selaku produsen pendapatannya berkurang karena harga gabah yang menurun. Persoalan yang sama yang dihadapi juga oleh pelaku lain dalam agroindustri perberasan, seperti pedagang, penggilingan padi, perantara gabah dan pedagang beras.

Aspek lainnya adalah harga komoditas padi dan turunannya memiliki trend yang meningkat dan sering berfluktuasi pada tingkat harga yang tinggi. Gejolak dan fluktuasi harga yang tidak terkendali menyebabkan ketidakpastian pelaku usaha dan meresahkan konsumen. Sebagai komoditas yang mempengaruhi ketersediaan bahan baku produk pangan, gejolak harga dan ketersediaan yang terjadi berpotensi menimbulkan dampak ekonomi, sosial, dan politik, secara nasional dan berpengaruh terhadap inflasi sebesar 9\% (BPS 2015). Salah satu faktor yang menyebabkan fluktuasi harga adalah mutu dari beras yang dijual di pasaran. Rendahnya mutu beras hasil gilingan dipengaruhi oleh beberapa hal yaitu: kondisi gabah yang digiling sudah rusak, bentuk geometris gabah, tingkat kekerasan, kualitas gabah yang diindikasikan dengan kadar air yang belum memenuhi standar, derajat kemurnian gabah, gabah yang telah retak di dalamnya, teknologi penggilingan yang digunakan dan prosedur penggilingan (Budijanto dan Sitanggang 2011). Salah satu yang menjadi faktor tinggi/rendahnya mutu beras adalah teknologi penggilingan padi di tingkat petani. Penggilingan padi di Indonesia didominasi oleh penggilingan padi skala kecil. Menurut Patiwiri (2004), penggilingan padi skala kecil menggunakan konfigurasi mesin husker, ayakan sederhana, dan polisher yang masih dioperasikan secara manual dengan kapasitas 0,3-0,7 ton beras/jam. Di Indonesia terdapat 180 ribu unit penggilingan padi yang didominasi oleh Penggilingan Padi Kecil (PPK) sebesar 169 ribu unit atau 92,8\%, disusul Penggilingan Padi Sedang (PPS) sebesar 4,7\%, skala lain-lain 1,3\%, dan Penggilingan Padi Besar (PPB) sebesar 1,1\% (BPS, 2015).

Pemahaman standar mutu beras ditingkat penggilingan maupun pedagang masih mengacu kepada harga beras yang ditawarkan (Rachmat et al. 2006). Kriteria mutu beras yang dianggap baik menurut pedagang beras pasar adalah apabila memenuhi kriteria yang baik untuk parameter derajat sosoh/putih, persentase beras kepala, kadar air (kering), dan kepulenan nasi (Budijanto dan Sitanggang 2011). Faktor lainnya yang menyebabkan rendahnya mutu beras antara lain: kualitas padi yang rendah, kinerja mesin penggilingan padi tidak optimal, faktor eksternal lainnya seperti penyimpanan dan pengemasan, petani yang belum sepenuhnya menerapkan GHP (Good Handling Practice), GMP (Good Milling Practice), dan masih dijumpai model penggilingan padi satu alur (phase) (Mahendra et al., 2016).

Kabupaten Karawang merupakan salah satu daerah penyangga pasokan beras nasional. Pemerintah Daerah berupaya untuk menjaga kinerja pasokan beras. Kinerja pasokan yang ada saat ini jika ditinjau dari aspek agroindustri maupun agribisnis perberasan, usaha peningkatan produksi maupun mutu beras adalah dua variabel yang sama penting. Peningkatan produksi padi belum diimbangi dengan peningkatan kualitas dan harga. Mutu beras di pasaran beragam karena seringkali ditemukannya manipuasi mutu pada beberapa pelaku rantai pasok. Oleh karena itu perlunya upaya dengan melakukan kajian mutu terhadap beras yang ada saat ini, untuk melihat pencapaian kinerja mutu yang dihasilkan. Selain itu juga melihat penerapan GMP dan GHP di tingkat penggilingan padi. Penelitian ini bertujuan (1) mengevaluasi mutu dan dan (2) mengevaluasi penerapan Good Handling Practices (GHP) dan Good Manufacturing Practices (GMP) pada penanganan pascapanen padi di tingkat penggilingan terhadap mutu beras yang dihasilkan. Menurut Reza (2004), pendekatan terhadap cara penanganan pangan yang baik (Good Handling Practices atau GHP) dan cara pengolahan pangan yang baik (Good Manufacturing Practices atau GMP) dapat dilakukan sebagai upaya penjaminan mutu produk pertanian. Pedoman GHP meliputi (1) persyaratan dan tata cara pelaksanaan proses panen; (2) penanganan pasca panen; (3) standardisasi mutu; (4) lokasi, (5) bangunan; (6) peralatan dan mesin; (7) bahan perlakuan, (8) wadah dan pembungkus; (9) tenaga kerja; (10) Keamanan dan Keselamatan Kerja (K3); (11) pengelolaan lingkungan; (12) pencatatan, pengawasan dan penelusuran balik; (13) sertifikasi; dan (14) pembinaan dan pengawasan (Kementan, 2015). Pedoman GMP meliputi persyaratan dan tata cara penggilingan padi terkait (1) prasarana dan sarana; (2) proses produksi; (3) penyimpanan; (4) keamanan dan keselamatan kerja serta pengelolaan lingkungan; (5) kesehatan dan kebersihan pekerja; (6) pengawasan, pencatatan dan penelusuran balik; (7) sertifikasi; dan (8) pembinaan (Kementan, 2008).

\section{METODE PENELITIAN}

\section{Waktu dan Tempat Penelitian}

Penelitian survei dilakukan di penggilingan padi di Kabupaten Karawang Jawa Barat. Analisis mutu beras dilaksanakan di Laboratorium Mutu Beras Karawang dan Laboratorium Pangan Universitas Sahid Jakarta. Penelitian dilaksanakan pada bulan Juni 2018 sampai dengan Desember 2018. 


\section{Tahapan Penelitian}

Penelitian ini terdiri dari beberapa tahapan penelitian yaitu (1) penentuan sampel (2) pengumpulan data (3) penilaian kesesuaian GHP dan GMP (4) pengolahan dan analisis data. Lebih jelasnya dapat dilihat pada diagram tahapan penelitian (Gambar 1).

\section{Penentuan Sampel dan Pengumpulan Data}

Identifikasi dan penentuan responden untuk analisis mutu gabah dan beras di kabupaten Karawang dilakukan dengan metode probablity sampling dan snowball sampling dari 30 kecamatan yang ada di Kabupaten Karawang dan dipilih 9 kecamatan yang akan diambil sampel beras untuk di analisis di laboratorium. Sampel beras yang diambil meliputi beras Kecamatan Lemahabang (LG), beras Kecamatan Rawamerta (RA), beras Kecamatan Telagasari (TI), beras Kecamatan Tempuran (TN), beras Kecamatan Majalaya (MA), beras Kecamatan Cilamaya (CA), beras Kecamatan Kutawaluyo (KO), beras Kecamatan Karawang Timur (KT), beras
Kecamatan Karawang Timur (KT), beras Kecamatan Cilebar (CR) dan beras PB Kecamatan Cilebar (PBCR).

Sampling beras yang didapat dilakukan analisis mutu beras di laboratorium sesuai parameter yang telah ditetapkan oleh SNI. Dari 11 sampling beras diambil dua sampling penggilingan padi sedang dan dua sampling penggilingan padi kecil untuk dilakukan analisis penerapan GHP dan GMP. Penentuan responden penggilingan padi kecil maupun padi sedang dilakukan berdasarkan parameter frekuensi dan volume pasokan beras. Penggilingan padi dengan nilai frekuensi dan volume pasokan tertinggi diasumsikan menerapkan GHP dan GMP dengan baik sehingga menghasilkan beras bermutu tinggi. Sebaliknya, responden dengan nilai frekuensi dan volume pasokan terendah diasumsikan menerapkan GHP dan GMP kurang baik sehingga menghasilkan beras bermutu rendah

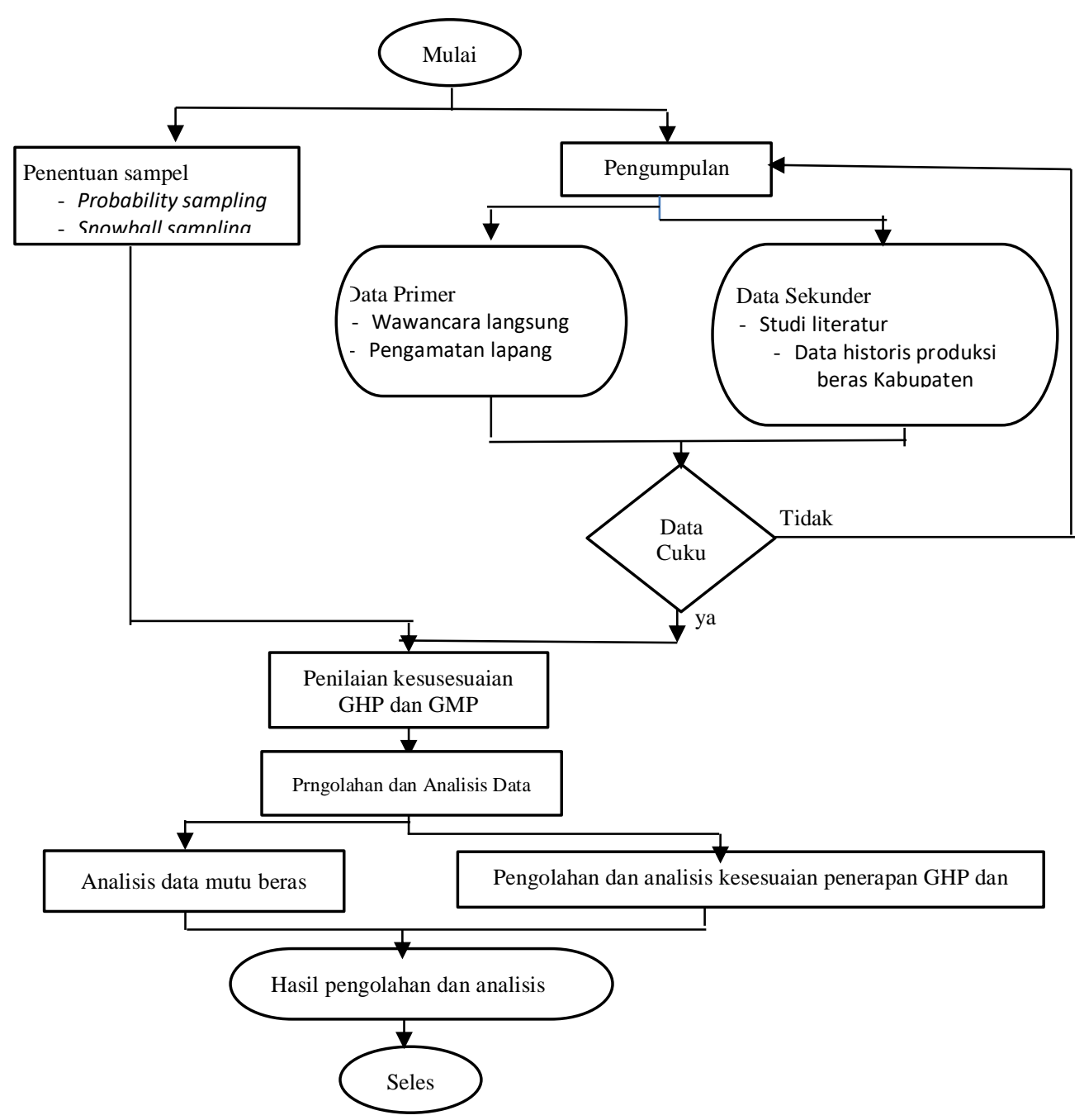

Gambar 1. Digram alir tahapan penelitian 
Pengumpulan data meliputi data primer dan sekunder pada penelitian ini dilakukan dengan cara (1) wawancara, diskusi permasalahan seputar mutu dan pasokan beras dengan pihak petani dan pelaku industri beras, (2) studi literatur, hasil penelitan sebelumnya, jurnal ilmiah dan dokumentasi data meliputi data produksi beras, laporan mutu beras di penggilingan.

\section{Analisis Mutu Beras}

Pada tahun 2017, Kementerian Pertanian mengeluarkan Peraturan Menteri Pertanian Nomor: 31/Permentan/PP.130/8/2017 tentang Kelas Mutu Beras (Kementan 2017 ) sebagai tindak lanjut dari Peraturan Menteri Perdagangan Nomor:57/MDAG/PER/8/2017 tentang Penetapan Harga Eceran Tertinggi (HET) beras (Kemendag, 2017). Dalam Kementan $\left(2017^{\mathrm{b}}\right)$, beras dikategorikan menjadi kelas mutu Premium dan Medium berdasarkan parameter mutu kadar air, beras kepala, butir patah, butir merah, benda asing, butir gabah, dan derajat sosoh (Tabel 1).

Analisis mutu fisik beras, meliputi pengujian kadar air, beras kepala, butir patah, dan derajat sosoh. Identifikasi kelas mutu beras dilakukan dengan membandingkan hasil analisis mutu fisik skala laboratorium dengan persyaratan dalam Peraturan Menteri Pertanian Nomor: 31/Permentan/ PP.130/8/2017.

\section{Analisis Kadar Air}

Kadar air beras menunjukkan persentase kandungan air butiran beras yang dinyatakan dalam basis basah (bb) (Kementan, 2015). Pengukuran kadar air beras dilakukan menggunakan metode primer berdasarkan AOAC (1990). Sejumlah lima gram contoh beras dioven dengan suhu $105^{\circ} \mathrm{C}$ selama 72 jam. Persamaan perubahan kadar air beras dengan metode primer sebagai berikut:

$$
K A B(\% b b)=\frac{A-B}{A-C} \times 100 \%
$$

Keterangan: $\mathrm{KA}=$ kadar air, $\mathrm{bb}=$ berat basah, $\mathrm{A}=$ berat cawan + sampel sebelum dikeringkan, $\mathrm{B}=$ berat cawan + sampel setelah dikeringkan, dan $\mathrm{C}=$ berat cawan.

\section{Beras Kepala Dan Butir Patah}

Beras kepala merupakan butiran beras berukuran lebih besar atau sama dengan 0,8 bagian dari butir beras utuh. Butir patah adalah butiran beras dengan ukuran lebih besar 0,2 sampai dengan lebih kecil 0,8 bagian butir beras utuh. Pengukuran parameter mutu beras kepala dan butir patah dilakukan berdasarkan metode SNI 6128:2015. Sejumlah $100 \mathrm{~g}$ sampel beras dimasukkan ke dalam cylinder separator dan ayakan diameter 4,2 mm untuk memisahkan beras kepala dan butir patah. Butiran beras kepala, dan butir patah yang diperoleh kemudian ditimbang dan dihitung persentasenya menggunakan rumus:
$B K(\%)=\frac{B}{A} \times 100 \%$
$B P(\%)=\frac{C}{A} \times 100 \%$

Keterangan: $\mathrm{BK}=$ beras kepala, $\mathrm{BP}=$ beras patah, $\mathrm{A}=$ berat sampel beras; $\mathrm{B}=$ berat beras kepala; $\mathrm{C}=$ berat butir patah.

Tabel 1. Persyaratan Kelas Mutu Beras Berdasarkan Peraturan Menteri Pertanian Nomor: 31/Permentan/PP.130/8/2017

\begin{tabular}{|c|c|c|c|}
\hline \multirow{2}{*}{$\begin{array}{l}\text { Komponen } \\
\text { mutu }\end{array}$} & \multirow[t]{2}{*}{ Satuan } & \multicolumn{2}{|c|}{ Kriteria mutu } \\
\hline & & Premium & Medium \\
\hline $\begin{array}{l}\text { Kadar } \\
\text { (maks) }\end{array}$ & $\%$ & 14 & 14 \\
\hline $\begin{array}{l}\text { Beras kepala } \\
(\min )\end{array}$ & $\%$ & 85 & 75 \\
\hline $\begin{array}{l}\text { Butir patah } \\
\text { (maks) }\end{array}$ & $\%$ & 15 & 25 \\
\hline $\begin{array}{l}\text { Butir menir } \\
\text { (maks) }\end{array}$ & $\%$ & 0 & 5 \\
\hline $\begin{array}{l}\text { Butir merah } \\
\text { (maks) }\end{array}$ & $\%$ & 0 & 5 \\
\hline $\begin{array}{l}\text { Butir } \\
\text { kuning/rusak } \\
\text { (maks) }\end{array}$ & $\%$ & 0 & 5 \\
\hline $\begin{array}{l}\text { Butir kapur } \\
\text { (maks) }\end{array}$ & $\%$ & 0 & 5 \\
\hline $\begin{array}{l}\text { Benda asing } \\
\text { (maks) }\end{array}$ & $\%$ & 0 & 0,05 \\
\hline $\begin{array}{l}\text { Butir gabah } \\
\text { (maks) }\end{array}$ & $\begin{array}{c}\text { butir/100 } \\
\mathrm{g}\end{array}$ & 0 & 1 \\
\hline $\begin{array}{l}\text { Derajat } \\
\text { sosoh (min) }\end{array}$ & $\%$ & 95 & 95 \\
\hline
\end{tabular}

Sumber: Kementan $\left(2017^{\mathrm{b}}\right)$

\section{Derajat Sosoh}

Derajat sosoh didefinisikan sebagai tingkat terlepasnya lapisan perikarp, testa, aleuron, dan lembaga dari butiran beras (Kementan, 2015). Penentuan kuantitatif derajat sosoh dilakukan berdasarkan metode SNI 6128:2015. Sejumlah 15-20 gram gabah/beras dimasukkan ke dalam probe. Probe tersebut dimasukkan ke dalam alat ukur derajat putih, yaitu rice whiteness tester tipe Satake C-600. Nilai derajat putih yang dihasilkan dari alat dikonversi menjadi derajat sosoh menggunakan tabel konversi SNI 6128:2015.

\section{Penilaian penerapan GHP dan GMP}

Parameter penilaian GHP mengacu pada Peraturan Menteri Pertanian Nomor: 22/Permentan/HK.140/4/2015 dan pedoman GMP mengacu pada Peraturan Menteri Pertanian Nomor: 35/Permentan/OT.140/7/2008, keduanya mempunyai pengaruh baik terhadap aspek mutu maupun keamanan pangan. Kesesuaian penerapan GHP dan GMP di tingkat penggilingan padi dinilai berdasarkan 
praktek GHP dan GMP oleh responden yang mempengaruhi mutu beras. Persentase penerapan GHP dan GMP ditingkat penggilingan kecil dan penggilingan besar dilakukan tabulasi dan selanjutnya dianalisis secara deskriptif. Tingkat kesesuaian penerapan GHP dan GMP dihitung berdasarkan metode Handayani et al. (2013) dengan menggunakan rumus:

$T K(\%)=\frac{A}{B} \times 100 \%$

Keterangan: $\mathrm{TK}=$ tingkat kesesuaian, $\mathrm{A}=$ kesesuaian terhadap Good Practices, B = jumlah parameter penilaian Good Practices

\section{Pengolahan dan Analisis Data}

Data sampel gabah dan beras dianalisis di laboratorium mutu untuk mengetahui mutu gabah dan beras sedangkan data kesesuaian GHP dan GMP diolah menggunakan metoda tabulasi dan dianalisis secara deskriptif.

\section{HASIL DAN PEMBAHASAN}

\section{Evaluasi Analisis Mutu Beras}

Hasil analisis mutu beras berdasarkan kadar air, beras kepala, butir patah dan derajat sosoh menunjukkan bahwa beras petani sampel yang diambil dari 9 kecamatan yang ada di Kabupaten Karawang termasuk dalam kategori mutu medium menurut persyaratan kelas mutu beras berdasarkan Peraturan Menteri Pertanian Nomor: 31/Permentan/PP.130/8/2017. Hasil analisis mutu beras secara keseluruhan dapat dilihat pada Tabel 2 .

\section{Kadar Air}

Hasil analisis menunjukkan bahwa kadar air beras sampel bervariatif mulai dari $7,1 \%$ hingga $14,2 \%$. Berdasarkan parameter mutu kadar air beras sampel memenuhi persyaratan mutu beras medium dan premium dengan kadar air maksimal yang dipersyaratkan adalah sebesar 14\%. Tinggi atau rendahnya kadar air beras dipengaruhi oleh kadar air gabah kering giling (GKG). Hasil analisis menunjukkan bahwa kadar air GKG berada pada kisaran $7,1 \%$ - 13,7\%. Secara umum, proses pengeringan gabah telah dilakukan pada lantai jemur yang baik. Meskipun demikian, petani umumnya tidak mempunyai alat ukur kadar air sehingga operator melakukan pengendalian mutu proses pengeringan dengan menduga tingkat kekeringan gabah secara subyektif. Selain kadar air gabah yang rendah, ruang penyimpanan yang lembab (kelembaban udara 79-87\% dan suhu $30-33,8^{\circ} \mathrm{C}$ ), dan pengendalian mutu di gudang penyimpanan yang masih lemah karena tidak dilengkapi dengan alat pengontrol suhu dan kelembaban ruangan diduga menyebabkan kadar air beras tinggi. Menurut Fernandyet al. (2012), gabah dengan kadar air 14\% bersifat stabil selama penyimpanan karena laju penyerapan kadar air terjadi sangat lambat sehingga tidak memudahkan penyerapan air kembali. Pada kondisi tersebut gabah aman disimpan karena panas yang dihasilkan oleh respirasi butiran maupun mikroorganisme tidak cukup untuk meningkatkan suhu dan kelembaban butiran. Pada kelembaban udara 65-95\% dan suhu 30-33,8 ${ }^{\circ} \mathrm{C}$, beras dengan kadar air $15,5 \%$ relatif stabil selama penyimpanan dibandingkan beras yang kadar airnya 13,2\% dan $13 \%$ karena mendekati kondisi kadar air kesetimbangan atau Equilibrium Moisture Content (EMC) beras, yaitu pada kisaran 15,5-18,8\%. Penyimpanan pada kelembaban udara rendah diperlukan untuk mengurangi penyerapan air dari udara ke beras dan menekan aktivitas mikroorganisme dan jamur (Ratnawati et al., 2013).

\section{Beras Kepala Dan Butir Patah}

Beras yang diambil sebagai sampel mempunyai persentase beras kepala yang berkisar antara paling rendah $64,6 \%$ hingga yang paling tinggi $82,0 \%$. Dapat dilihat dari tabel hasil analisis mutu beras kepala, tidak ada sampel yang memenuhi persyaratan mutu beras premium, sedangkan untuk beras medium hanya dua kecamatan yaitu Kecamatan Rawamerta dan Kutawaluyo, sedangkan untuk beras butir patah, yang memenuhi persyaratan mutu beras premium hanya satu sampel yaitu beras Kecamatan Telagasari, yang memenuhi persyaratan mutu beras medium ada empat sampel yaitu beras Kecamatan Lemahabang, Rawamerta, Majalaya, dan Kutawaluyo.

Tabel 2 Hasil analisis mutu beras penggilingan di Kabupaten Karawang

\begin{tabular}{|c|c|c|c|c|c|c|c|c|c|c|c|}
\hline \multirow{2}{*}{$\begin{array}{l}\text { Komponen } \\
\text { Mutu (\%) }\end{array}$} & \multicolumn{11}{|c|}{ Hasil Analisis Mutu Beras } \\
\hline & LG & RA & TI & $\mathrm{TN}$ & MA & $\mathrm{CA}$ & $\mathrm{KO}$ & KT & PB-KT & CR & $\mathrm{PB}-\mathrm{CR}$ \\
\hline Kadar Air & $10^{1)}$ & $7,1^{1)}$ & $14,2^{3)}$ & $13,1^{2)}$ & $7,7^{1)}$ & $11,6^{2)}$ & $11,3^{2)}$ & $10,8^{2)}$ & $13,1^{2)}$ & $11,03^{2)}$ & $13,7^{2)}$ \\
\hline Beras Kepala & $82,0^{3)}$ & $76,3^{3)}$ & $70,6^{3)}$ & $70,42^{3)}$ & $76,6^{3)}$ & $72,4^{3)}$ & $76,6^{3)}$ & $66,5^{3)}$ & $68,5^{3)}$ & $68,2^{3)}$ & $64,6^{3)}$ \\
\hline Butir Patah & $16,0^{2)}$ & $19,2^{2)}$ & $6,6^{1)}$ & $25,8^{3)}$ & $20,3^{2)}$ & $25,1^{3)}$ & $22,5^{2)}$ & $33,0^{3)}$ & $31,3^{3)}$ & $28,7^{3)}$ & $33,8^{3)}$ \\
\hline Derajat Sosoh & $90^{3)}$ & $90^{3)}$ & $95^{1)}$ & $95^{1)}$ & $90^{3)}$ & $95^{1)}$ & $100^{1)}$ & $95^{1)}$ & $95^{1)}$ & $95^{1)}$ & $95^{1)}$ \\
\hline Keterangan: & & & & & & $\begin{array}{l}\text { mium } \\
\text { dium }\end{array}$ & & & & & \\
\hline
\end{tabular}


Selebihnya sampel beras tidak memenuhi persyaratan mutu premium ataupun medium. Butir patah tinggi dapat disebabkan oleh beberapa faktor, diantaranya kadar air gabah, kondisi peralatan dan mesin, serta subyektivitas operator (Hasbullah dan Dewi 2012). Upaya perbaikan mutu fisik beras dapat dilakukan melalui revitalisasi mesin. Menurut Shimizu dan Kimura (2008), gabah dengan kadar air terlalu rendah $(6,4$ persen berat basah) akan mengalami perubahan dimensi butiran selama penyimpanan yang dapat mengakibatkan keretakan pada beras. Menurut Setyono et al. (2008) dan Millati et al. (2016), gabah dengan kadar air kurang dari 13 persen, butiran gabah menjadi retak dan menghasilkan banyak butir patah pada proses penggilingan.

Persentase butir patah pada beras dipenggilingan sedang dan kecil diduga dipengaruhi oleh kondisi peralatan dan mesin penggilingan padi sehingga mempengaruhi mutu beras yang dihasilkan. Kondisi mesin yang sudah berumur lebih dari 10 tahun dan penggunaan mesin pengupas kulit gabah (dehusker) tipe rubber roll dan mesin penyosoh (polisher) tipe friksi dimana pengaturan jarak rubber roll pada mesin dehusker tipe friksi dilakukan secara manual atau trial and eror yang bersifat subyektif. Menurut Hasbullah dan Dewi (2012) ukuran dimensi gabah memerlukan pengaturan jarak rubber roll untuk meminimalkan butir patah dan menir, Sutrisno dan Achmad (2008) melaporkan bahwa jarak rubber roll untuk menghasilkan beras pecah kulit dengan mutu terbaik berdasarkan uji penggilingan untuk varietas pandan wangi adalah $1,5 \mathrm{~mm}$ dan $1,2 \mathrm{~mm}$ untuk beras varietas IR 77 berdasarkan uji penggilingan. Menurut Hasbullah dan Bantacut (2007), penggunaan mesin length grader diperlukan untuk memisahkan beras kepala dan butir patah. Setyono et al. (2008) melaporkan bahwa umumnya penggilingan padi maupun pedagang pasar dari beberapa kabupaten di Jawa Barat menggunakan mesin berumur 11-20 tahun. Hal tersebut menyebabkan beras mempunyai persentase butir patah tinggi sehingga hanya memenuhi kelas mutu terendah. Hasil survei menunjukkan bahwa operator yang mengoperasikan mesin penggilingan padi umumnya telah mempunyai pengalaman lebih dari tiga tahun, namun belum pernah mengikuti pelatihan atau tersertifikasi mengenai keterampilan pascapanen padi.

Derajat sosoh beras yang diambil sebagai sampel umumnya memenuhi persyaratan mutu beras medium dan juga premium (nilai derajat sosoh minimal 95\%). Derajat sosoh beras dipengaruhi oleh konfigurasi dan kondisi mesin penggilingan padi. Menurut Hasbullah dan Bantacut (2007), mesin penyosohan (whitening machine) dan atau pengkilapan (shinning machine) diperlukan untuk menghasilkan beras dengan nilai derajat sosoh 85-95 persen. Peningkatan mutu derajat sosoh beras dapat dilakukan melalui perbaikan konfigurasi dan/atau modernisasi mesin penggilingan padi. Kondisi ini menggambarkan dari kriteria derajat sosoh beras yang dihasilkan dari sembilan kecamatan telah memenuhi standar mutu yang dipersyaratkan.

\section{Penilaian Penerapan GHP dan GMP di tingkat Penggilingan Padi.}

Hasil penilaian dalam penerapan GHP dan GMP untuk sampel penggilingan padi kecil dan penggilingan padi sedang dapat dilihat pada Tabel 3 dan 4. Dari Tabel 3 dan 4 diketahui bahwa penerapan GHP di penggilingan padi kecil baru berkisar $42 \%$ dan penggilingan padi sedang 50\%. Sedangkan untuk penerapan GMP pada penggilingan padi kecil sebesar $69 \%$ dan untuk penggilingan padi sedang $92 \%$. Nilai kesesuaian penerapan GHP dan GMP diperoleh dari rumus pada metode yang digunakan Handayani et al. 2013. Kurangnya penerapan GHP dan GMP pada penggilingan padi terutama penggulingan padi kecil dikarenakan tidak dilakukannya sortasi terhadap hasil panen atau produksi gabah, tidak adanya pembersihan hasil panen dari kotoran yang melekat, kurang kehatihatian dalam penanganan, tidak dilakukan pengkelasan mutu beras sesuai SNI. Dalam hal kemasan, belum menggunakan kemasan yang dapat melindungi produk dari kerusakan dalam pengangkutan dan/atau penyimpanan dan tidak menggunakan kemasan yang sesuai dengan sifat produk.

Secara teknis bangunan, semua penggilingan padi responden luas, cukup kuat. Selain itu, rumput, perdu, dan gulma penggilingan padi semua responden terpotong rapi dan peralatan tersimpan baik. Semua ventilasi penggilingan padi responden cukup nyaman dan menjamin peredaran udara dengan baik, dapat menghilangkan kondensat uap, asap, bau, debu, dan panas, udara yang mengalir tidak mencemari produk, namun lubang ventilasi semua responden tidak ada yang dilengkapi pelindung untuk mencegah masuknya hama, debu, kotoran, dan tidak mudah dibersihkan. Bangunan penggilingan padi responden tidak dirancang agar dapat mencegah masuknya binatang pengerat, hama dan serangga, dan mempunyai jendela yang ditutup dengan kawat untuk mencegah masuknya serangga. 
Tabel 3. Penerapan GHP di penggilingan padi kecil dan sedang dan pengaruhnya terhadap mutu beras

\begin{tabular}{|c|c|c|c|c|}
\hline No & Parameter Penilaian & PPK & PPS & $\begin{array}{c}\text { Pengaruh } \\
\text { terhadap Mutu } \\
\text { Beras }\end{array}$ \\
\hline 1 & $\begin{array}{l}\text { Hasil panen berupa gabah telah diperlakukan dengan } \\
\text { hati-hati supaya tidak kotor, berjamur, membusuk }\end{array}$ & $100 \%$ & $100 \%$ & Butir rusak \\
\hline 2 & Dilakukan sortasi terhadap hasil panen/produksi gabah & $0 \%$ & $0 \%$ & $\begin{array}{l}\text { Benda Asing dan } \\
\text { butir rusak }\end{array}$ \\
\hline 3 & Pembersihan hasil panen dari kotoran dan OPT & $0 \%$ & $0 \%$ & $\begin{array}{l}\text { Benda Asing dan } \\
\text { butir rusak }\end{array}$ \\
\hline 4 & $\begin{array}{l}\text { Pembersihan sudah dilakukan dengan hati-hati agar padi } \\
\text { tidak menjadi cacat }\end{array}$ & $0 \%$ & $0 \%$ & Butir rusak \\
\hline 5 & $\begin{array}{l}\text { Produk cacat sudah dipisahkan dan tidakdipasarkan } \\
\text { sebagai produk segar }\end{array}$ & $0 \%$ & $0 \%$ & Butir rusak \\
\hline 6 & $\begin{array}{l}\text { Pengeringan gabah dengan cara penjemuran matahari } \\
\text { sudah dilakukan menggunakan lantai jemur }\end{array}$ & $100 \%$ & $100 \%$ & Benda asing \\
\hline 7 & $\begin{array}{l}\text { Hasil panen yang sudah dijemur dan dibersihkan } \\
\text { telah dilakukan pengkelasan sesuai dengan SNI }\end{array}$ & $0 \%$ & $0 \%$ & $\begin{array}{l}\text { Butir } \\
\text { kuning/rusak, } \\
\text { butir kapur, } \\
\text { benda asing }\end{array}$ \\
\hline 8 & $\begin{array}{l}\text { Hasil panen telah diklasifikasikan sesuai kelas standar } \\
\text { mutu }\end{array}$ & $0 \%$ & $0 \%$ & Beras kepala \\
\hline 9 & $\begin{array}{l}\text { Produk hasil panen dikemas sesuai dengan kelas produk, } \\
\text { mengikuti ketentuan standar kelas (grading) }\end{array}$ & $0 \%$ & $0 \%$ & Beras kepala \\
\hline 10 & $\begin{array}{l}\text { Kemasan dapat melindungi produk dari kerusakan dalam } \\
\text { pengangkutan dan/atau penyimpanan }\end{array}$ & $0 \%$ & $0 \%$ & Beras kepala \\
\hline 11 & Bahan kemasan telah disesuaikan dengan sifat produk & $0 \%$ & $0 \%$ & Beras kepala \\
\hline 12 & $\begin{array}{l}\text { Kemasan harus kuat, dapat menahan beban tumpukan } \\
\text { dan melindungi fisik serta tahan terhadap goncangan } \\
\text { serta dapat mempertahankan keseragaman }\end{array}$ & $100 \%$ & $100 \%$ & Beras kepala \\
\hline 13 & $\begin{array}{l}\text { Suhu, tekanan, dan kelembaban udara ruang } \\
\text { penyimpanan sesuai dengan karakteristik gabah }\end{array}$ & $0 \%$ & $0 \%$ & Kadar Air \\
\hline 14 & $\begin{array}{l}\text { Spesifikasi alat/mesin pengangkutan sesuai dengan } \\
\text { karakteristik gabah }\end{array}$ & $0 \%$ & $0 \%$ & Beras kepala \\
\hline 15 & $\begin{array}{l}\text { Bangunan dirancang agar mencegah masuknya binatang } \\
\text { pengerat, hama dan serangga }\end{array}$ & $0 \%$ & $0 \%$ & $\begin{array}{l}\text { Kadar air dan } \\
\text { benda asing }\end{array}$ \\
\hline 16 & Ruangan penanganan dan ruangan pelengkap terpisah & $0 \%$ & $100 \%$ & $\begin{array}{l}\text { Kadar air dan } \\
\text { benda asing }\end{array}$ \\
\hline 17 & $\begin{array}{l}\text { Dinding kedap air, tidak mudah mengelupas dan mudah } \\
\text { dibersihkan }\end{array}$ & $100 \%$ & $100 \%$ & Kadar Air \\
\hline 18 & Atap terbuat dari bahan yang tidak mudah bocor & $100 \%$ & $100 \%$ & Kadar Air \\
\hline 19 & $\begin{array}{l}\text { Jendela dan ventilasi cukup untuk menjamin pertukaran } \\
\text { udara }\end{array}$ & $100 \%$ & $100 \%$ & Kadar Air \\
\hline 20 & $\begin{array}{l}\text { Ditutup dengan kawat untuk mencegah masuknya } \\
\text { serangga }\end{array}$ & $0 \%$ & $100 \%$ & $\begin{array}{l}\text { Kadar air dan } \\
\text { benda asing }\end{array}$ \\
\hline 21 & Peralatan sesuai tujuan proses & $100 \%$ & $100 \%$ & Beras Kepala \\
\hline 22 & $\begin{array}{l}\text { Wadah dan pembungkus dapat melindungi dan } \\
\text { mempertahankan mutu Beras }\end{array}$ & $100 \%$ & $100 \%$ & $\begin{array}{l}\text { Beras } \\
\text { Kepala,kadar air }\end{array}$ \\
\hline 23 & Wadah dan pembungkus tidak mempengaruhi mutu beras & $100 \%$ & $100 \%$ & $\begin{array}{l}\text { Beras } \\
\text { Kepala,kadar air }\end{array}$ \\
\hline 24 & $\begin{array}{l}\text { Wadah dan pembungkus tahan/tidak berubah selama } \\
\text { pengangkutan dan peredaran }\end{array}$ & $100 \%$ & $100 \%$ & $\begin{array}{l}\text { Beras } \\
\text { Kepala,kadar air }\end{array}$ \\
\hline \multicolumn{2}{|r|}{ Implementasi GHP } & $42 \%$ & $50 \%$ & \\
\hline
\end{tabular}

Ket : PPK= Penggilingan Padi Kecil

PPS = Penggilingan Padi Sedang 
Tabel 4. Penerapan GMP di penggilingan padi kecil dan sedang dan pengaruhnya terhadap mutu beras

\begin{tabular}{|c|c|c|c|c|}
\hline No & Parameter Penilaian & PPK & PPS & $\begin{array}{l}\text { Pengaruh terhadap } \\
\text { Mutu Beras }\end{array}$ \\
\hline 1 & $\begin{array}{l}\text { Lantai padat, keras dan kedap air, tahan } \\
\text { air/garam/asam/basa }\end{array}$ & $100 \%$ & $100 \%$ & Kadar Air \\
\hline 2 & $\begin{array}{l}\text { Permukaan lantai rata,halus, tidak licin, mudah } \\
\text { dibersihkan, kedap air }\end{array}$ & $100 \%$ & $100 \%$ & Kadar Air \\
\hline 3 & Dinding kedap air & $100 \%$ & $100 \%$ & Kadar Air \\
\hline 4 & $\begin{array}{l}\text { Dinding halus, rata, berwarna terang, tidak mudah } \\
\text { terkelupas, tahan air/garam/asam/basa, mudah } \\
\text { dibersihkan, tahan lama }\end{array}$ & $0 \%$ & $100 \%$ & Kadar Air \\
\hline 5 & $\begin{array}{l}\text { Atap tahan lama, tahan air, tidak bocor, terbuat } \\
\text { dari bahan yang tidak mudah mengelupas, } \\
\text { minimum } 3 \mathrm{~m} \text { di atas lantai }\end{array}$ & $100 \%$ & $100 \%$ & Kadar Air \\
\hline 6 & $\begin{array}{l}\text { Langit-langit tidak berlubang atau retak, tahan } \\
\text { lama, mudah dibersihkan, minimum } 2,5 \mathrm{~m} \text { di atas } \\
\text { lantai, permukaan halus, rata, berwarna terang, } \\
\text { tidak mudah mengelupas, tidak bocor }\end{array}$ & $100 \%$ & $100 \%$ & Kadar Air \\
\hline 7 & $\begin{array}{l}\text { Jendela dilengkapi kasa pencegah serangga, tikus } \\
\text { dan lain-lain yang mudah dibersihkan }\end{array}$ & $0 \%$ & $0 \%$ & $\begin{array}{l}\text { Kadar Air dan benda } \\
\text { asing }\end{array}$ \\
\hline 8 & $\begin{array}{l}\text { Ventilasi cukup nyaman dan menjamin peredaran } \\
\text { udara dengan baik }\end{array}$ & $0 \%$ & $100 \%$ & Kadar Air \\
\hline 9 & $\begin{array}{l}\text { Lubang-lubang ventilasi dapat mencegah } \\
\text { masuknya hama, debu, kotoran, dan mudah } \\
\text { dibersihkan }\end{array}$ & $0 \%$ & $100 \%$ & $\begin{array}{l}\text { Kadar Air dan benda } \\
\text { asing }\end{array}$ \\
\hline 10 & Peralatan dan mesin sesuai dengan tujuan proses & $100 \%$ & $100 \%$ & $\begin{array}{l}\text { Kadar Air dan benda } \\
\text { kepala }\end{array}$ \\
\hline 11 & $\begin{array}{l}\text { Wadah dan pembungkus dapat melindungi dan } \\
\text { mempertahankan mutu beras }\end{array}$ & $100 \%$ & $100 \%$ & $\begin{array}{l}\text { Kadar Air dan benda } \\
\text { kepala }\end{array}$ \\
\hline 12 & $\begin{array}{l}\text { Wadah dan pembungkus dibuat dari bahan yang } \\
\text { tidak mengganggu kesehatan atau mempengaruhi } \\
\text { mutu beras }\end{array}$ & $100 \%$ & $100 \%$ & $\begin{array}{l}\text { Kadar Air dan benda } \\
\text { kepala }\end{array}$ \\
\hline 13 & $\begin{array}{l}\text { Wadah dan pembungkus tahan/tidak berubah } \\
\text { selama pengangkutan dan peredaran }\end{array}$ & $100 \%$ & $100 \%$ & $\begin{array}{l}\text { Kadar Air dan benda } \\
\text { kepala }\end{array}$ \\
\hline \multicolumn{2}{|c|}{ Kesesuaian penerapan GMP } & $69 \%$ & $92 \%$ & \\
\hline
\end{tabular}

Penyimpanan gabah tanpa menggunakan alas, pengendalian mutu pengeringan dan penggilingan secara subyektif, dan teknologi mesin penggilingan padi yang masih sederhana juga merupakan faktorfaktor kritis yang berpengaruh terhadap rendahnya mutu beras yang dihasilkan pada penggilingan. Halhal seperti diatas belum diterapkan secara baik oleh penggilingan padi kecil maupun sedang sehingga mempengaruhi mutu beras yang dihasilkan dari penggilingan tersebut dan berpengaruh terhadap rendahnya penilaian penerapan GHP dan GMP (Sarastuti et al., 2018). Penelitian yang dilakukan Soemantri et al., 2016, pendekatan teknis dengan menerapkan sistem mekanisasi diikuti oleh penerapan sistem manajemen mutu seperti GHP dan GMP yang tepat, dapat menurunkan susut panen dan pasca panen padi mulai $5,58 \%$ sampai dengan $10,14 \%$ atau setara dengan penyelamatan GKG sebesar 61.240 sampai 115.859 ton. Penerapan GHP dan GMP ini juga akan mendorong revitalisasi penggilingan yang dapat meningkatkan rendemen serta mutu beras yang dihasilkan.

Secara umum rendahnya penerapan GHP pada penggilingan padi kecil maupun sedang di Kabupaten Karawang disebabkan beberapa hal antara lain belum adanya sosialisasi yang menyeluruh terhadap petani mengenai pentingnya penerapan GHP di lingkungan penggilingan padi untuk meningkatkan mutu beras hasil panen, adanya keterbatasan sumber daya terutama untuk menerapkan GHP dan GMP yang baik akan membutuhkan investasi yang cukup besar untuk menciptakan lingkungan yang bersih untuk penanganan pasca panen padi yang dihasilkan petani, sementara berdasarkan pemahaman petani penerapan GHP dan GMP belum menunjukkan korelasi yang positif terhadap benefit yang akan mereka terima terutama terhadap mutu pasokan beras yang dihasilkan. Selain itu belum adanya pemberlakuan perundangan yang mengikat dalam penerapan GHP dan GMP ditingkat pengilingan padi petani. 


\section{KESIMPULAN DAN SARAN}

Hasil penelitian menunjukkan bahwa dari 11 sampel beras yang diproduksi di Kabupaten Karawang, berdasarkan kriteria mutu sesuai Peraturan Menteri Pertanian Nomor: 31/Permentan/PP.130/8/2017, menurut kriteria kadar air yang masuk dalam kelas mutu premium sebanyak $27 \%$ dan kelas mutu medium 64\%, berdasarkan kriteria beras kepala tidak ada yang memenuhi persyaratan mutu beras premium karena semua berada dibawah standar mutu beras premium, sedangkan untuk kriteria mutu beras medium dipenuhi oleh dua kecamatan, berdasarkan butir patah hampir tidak ada yang termasuk kedalam kelas premium (hanya 1 kecamatan) sedangkan yang termasuk kedalam kelas medium 36\% dan selebihnya dibawah standar mutu. Derajat sosoh beras sampel termasuk tinggi karena hampir semua sampel beras memiliki nilai derajat sosoh $95-100 \%$ sehingga masuk dalam kelas medium maupun premium.

Secara keseluruhan mutu beras di Kabupaten Karawang termasuk dalam persyaratan beras kelas medium. Hal ini sesuai dengan hasil penilaian penerapan GHP dan GMP ditingkat penggilingan kecil maupun sedang di Kabupaten Karawang dimana penerapan GHP masih sangat rendah yaitu sebesar $42 \%$ untuk penggilingan kecil dan 50\% untuk penggilingan sedang, sedangkan untuk penerapan GMP $69 \%$ untuk penggilingan padi kecil dan 92\% untuk penggilingan padi sedang. Beberapa penyebab dari hasil wawancara dari pelaku dalam penerapan GMP dan GHP adalah masih kurang tersosialisasinya mutu produk, nilai tambah dan manfaat yang belum dirasakan oleh petani dengan adanya penerapan GHP dan GMP, adanya resiko biaya yang harus ditambahkan dengan melakukan penerapan GMP dan GHP dengan baik, dan target pasar lokal yang dituju tidak membutuhkan persyaratan penerapan GHP dan GMP di penggilingan. Hal ini menjadi penyebab rendahnya mutu beras yang dihasilkan petani di Kabupaten Karawang.

\section{DAFTAR PUSTAKA}

Badan Standardisasi Nasional [BSN]. 2015. Standar Nasional Indonesia Beras. SNI 6128:2015. Jakarta (ID): Badan Standardisasi Nasional.

Badan Pusat Statistik [BPS]. 2015. Pendataan Industri Penggilingan Padi (PIPA). Katalog BPS. Jakarta (ID): Badan Pusat Statistik.

Fernandy GMA, Ratnawati, Buchori L. 2012. Pengaruh suhu udara pengering dan komposisi zeolit 3A terhadap lama waktu pengeringan gabah pada fluidized bed dryer. Jurnal Momentum. 8(2) : 6-10.

Handayani A, Sriyanto dan Sulistyawati I. 2013. Evaluasi mutu beras dan tingkat kesesuaian penanganannya (studi kasus di kabupaten
Karanganyar). Jurnal Litbang Provinsi Jawa Tengah. 11(1) : 113-124.

Hasbullah R dan Bantacut T. 2007. Teknologi pengolahan beras ke beras. Pangan. 18(1) : 23-37.

Hasbullah R dan Indaryani R. 2009. Penggunaan teknologi perontokan untuk menekan susut dan mempertahankan kualitas gabah. Keteknikan Pertanian. 23(2): 111-118.

Hasbullah R dan Dewi AR. 2012. Teknik penanganan pascapanen padi untuk menekan susut dan meningkatkan rendemen giling. Pangan. 21(1) : 17-28.

Kementerian Perdagangan [Kemendag]. 2017. Peraturan Menteri Perdagangan Nomor:57/M-DAG/PER/8/2017. Penetapan Harga Eceran Tertinggi (HET) Beras. Jakarta (ID): Kementerian Perdagangan.

Kementerian Pertanian [Kementan]. 2008. Peraturan Menteri Pertanian Nomor: 35/Permentan/OT.140/7/2008. Persyaratan dan Penerapan Cara Pengolahan Hasil Pertanian Asal Tumbuhan yang Baik. Jakarta (ID): Kementerian Pertanian

Kementerian Pertanian [Kementan]. 2015. Peraturan Menteri Pertanian Nomor: 22/Permentan/HK.140/4/2015. Pedoman Penanganan Pascapanen Hasil Pertanian Asal Tanaman Yang Baik. Jakarta (ID): Kementerian Pertanian

Kementerian Pertanian [Kementan]. 2017a. Ketersediaan Beras Nasional. https://www.pertanian.go.id/konsumsi2017/ $\mathrm{k}$ etersediaan/laporan_nbm. [Diakses 5 Mei 2018].

Kementerian Pertanian [Kementan]. 2017b. Peraturan Menteri Pertanian Nomor: 31/Permentan/ PP.130/8/2017. Kelas Mutu Beras. Jakarta (ID): Kementerian Pertanian.

Kementerian Pertanian [Kementan]. 2017c. Pedoman Teknis PUPM 2017 (Pengembangan Usaha Pangan Masyarakat). Jakarta (ID): Kementerian Pertanian.Mahendra PR, Dewi RK, Sumba IK. 2016. Pengawasan mutu beras pada perusahaan umum BULOG divisi regional Bali. Jurnal agribisnis dan agrowisata.5(3):597-606.

Patiwiri AW. 2004. Kondisi Dan Permasalahan Perusahaan Pengolahan Padi Di Indonesia. Prosiding Lokakarya Nasional Upaya Peningkatan Nilai Tambah Pengolahan Padi, Bogor. Bogor (ID): F-Technopark Fateta-IPB : 22-41.

Rachmat R, Thahir R, dan Gummert M. 2006 .The empirical relationship between price and quality of rice at market level in West Java. Indonesian Journal Agricultural Science. 7(1):27-33. 
Ratnawati, Djaeni M dan Hartono D. 2013. Perubahan kualitas beras selama penyimpanan. Pangan. 22(3) : 199- 208.

Shimizu N dan Kimura T. 2008. Measurement and fissuring of rice kernels during quasimoisture sorption by image analysis. Journal Cereal Science. 48(1) : 98-103.

Sarastuti, Usman A, dan Sutrisno. 2018. Analisis mutu beras dan penerapan sistem jaminan mutu dalam kegiatanpengembangan usaha pangan masyarakat. Jurnal Penelitian Pascapanen Pertanian. 15 (2): 63-72.

Setyono A, Kusbiantoro B, Jumali P dan Guswara A. 2008. Evaluasi Mutu Beras di Beberapa Wilayah Sentral Produksi Padi. Makalah disampaikan pada Seminar Nasional Inovasi Teknologi Padi Mengantisipasi Perubahan
Iklim Global Mendukung Ketahanan Pangan. Buku IV. Sukamandi (ID): Kementerian Pertanian : 1429-1448.

Soemantri AS, Prima L, dan Irpan BJ. 2016. Strategi peningkatan produksi beras melalui penekanan susut panen dan pascapanen dengan pendekatan sistem modeling: studi kasus Kabupaten Indramayu, Jawa Barat. Informatika Pertanian. 25 (2) : 249 - 260.

Sutrisno dan Achmad DR. 2008. Pengaruh ukuran dan bentuk gabah terhadap rendemen dan mutu beras giling. Makalah disampaikan pada Seminar Nasional Padi: 1505-1516. 